\title{
Influence of 17-alpha methyl testosterone on the production parameters of common carp (Cyprinus carpio L.) fry
}

\author{
${ }^{1}$ László Kovács - ${ }^{1}$ Ádám Simon $-{ }^{2}$ Dániel Minya - ${ }^{2}$ Dávid Homoki $-{ }^{1}$ Attila Kertész - ${ }^{1}$ Milán Fehér - \\ ${ }^{2}$ László Stündl - ${ }^{1}$ Péter Bársony \\ University of Debrecen Faculty of Agricultural and Food Sciences and Environmental Management, \\ ${ }^{1}$ Institute of Animal Science, Biotechnology and Nature Conservation, Debrecen, Hungary \\ ${ }^{2}$ Institute of Food Technology, Debrecen, Hungary \\ kovacs.laszlo@agr.unideb.hu
}

\section{SUMMARY}

\begin{abstract}
During our research we aimed at finding an answer as to what extent the different concentrations of 17-alpha methyl testosterone incorporated in the diet of common carp fries can influence the production parameters of the species, as well as how efficient their sexreversal can be with the use of this method. To this end, an aquarium experiment was conducted in the course of which four different hormone treatments were set and monitored. The fish feed was enriched with 17-alpha methyl testosterone in 50 ppm, 75 ppm, 100 ppm, 500 ppm dosages.

The obtained figures revealed that the hormone treatments had no influence on the production parameters and conservation of the common carp fries. Further on, our team is to determine the sex of the fish through the examination of gonads during autopsy when they reach the $500 \mathrm{~g}$ average weight.

Furthermore, a male specific test method which was supposed to be of great help in our attempt to select the sex-reversed specimens in the subsequent processes was also put to the trial. During the experiment the DNA-isolation of different sample types (muscle tissue, fin, mucus) of common carp with identified sex was successfully carried out. The extracted PCR product was examined with agarose gel. Our results indicated that the ccmf2 marker was applicable, however, the obtained figures were not reliable.
\end{abstract}

Keywords: common carp, sex-reversal, methyl testosterone, performance

\section{INTRODUCTION}

Common carp (Cyprinus carpio L.) is a native fish species in Europe and Asia. The carp is a type of freshwater fish, which -due to the natural geographical features of Hungary- is bred in some of the most significant ponds of the country (Molnár 2009). The ever-intensifying fish breeding in pond farms calls for a better understanding and application of production increasing methods. One of the possible solutions to this matter may be the exploitation of better somatic growth abilities in mono-sex seed carp stocks as opposed to those of the mixed-sex populations (Cherfas et al. 1996, Kocour et al. 2003, 2005). Establishing mono-sex seed carp stocks occurs on the basis of common protocols, which also applies to mother fish breeding. The production of motherfish stocks is accomplished by artificially induced gynogenesis and by the technique of sex-reversal through hormone treatment (Komen et al. 1988, 1991, 1992, 1993; Cherfas et al. 1993, Horváth and Orbán 1995, Ben Dom et al. 2001, Gomelsky 2003, Komen and Thorgaard 2007).

In the course of sex-reversal the aim is to convert the female fish specimens into phenotype males. This type of sex-reversal can be effectuated by steroidbased hormones (Shelton et al. 1995, Colborn et al. 1993, Damstra et al. 2002) The steroids are ingested into the body generally by oral administration, i.e. supplemented in the fish food or by dissolving in water (Piferrer 2001, Devlin and Nagahama 2002, Mubarik et al. 2011). The most frequently used androgen hormone is the 17-alpha methyl testosterone. It is a synthetic hormone which has fast absorbing qualities, does not accumulate in the body and quickly eliminates from the organism (Sumpter 2005).

The hormone treatment must be applied in the spawning phase, which is a sensitive period in the sexual development of the fish. During the treatment of gynogenic female common carp. Researchers found that along with a $20 \%$ mortality rate, a $80 \%$ sexreversal efficiency rate can be achieved if the fish are fed on ad-libitum of fish food supplemented with 100 ppm dosage of 17-alpha methyl testosterone for 44.80. days after hatching (Nagy et al. 1981, Hulak et al. 2007, Singh 2013, Jensi 2016). Other scientists, however, carried out treatments on mixed-sex stocks in a similar way. By applying different hormone concentrations, they obtained a $100 \%$ male rate together with a $100 \%$ stock conservation rate, on the basis of which the efficiency of the hormone treatment could be assessed (Mubarik et al. 2011).

Investigating the above problem, in our current research we seek to get an answer to the question as to what extent the different concentrations of 17-alpha methyl testosterone incorporated in the fish food can influence the production parameters of common carp fries as well as what effect this method has on their conservation. In the future we target at determining the success of the hormone treatment on the basis of female and male proportions. Furthermore, the usability of sample types (muscle tissue, fin, mucus) from different common carp specimens with identified sex is to be revealed by testing PCR markers (ccmf1, ccm2, ccm3) described by Chen et al. (2009, 2010). 


\section{MATERIALS AND METHODS}

\section{The preparation of 17 -alpha methyl testosterone solution}

The 17-alpha methyl testosterone (69240-5G, Sigma-Aldrich) was placed into $50 \mathrm{ml}$ Falcon test tubes (525-0159, VWR) and $30 \mathrm{ml} 70 \%$ pharmacy alcohol was added to it. During the preparation of the solutions, XB 120A Precisa analytical balance scales were used. The dissolution of the hormones was accelerated with the help of a vortex test tube shaker (Velp Scientifica, $\mathrm{zx}^{3}$ ) used for 1 minute at maximum speed. The solutions were stored in the tubes covered with aluminum foil.

\section{The application of 17-alpha methyl testosterone to the feed}

The previously prepared $30 \mathrm{ml}$ solutions with different concentrations (50 ppm, 75 ppm, 100 ppm, $500 \mathrm{ppm}$ ) were applied separately to $0.5 \mathrm{~mm}$ and 1.1 $\mathrm{mm}$ fish feed (Mubarik et al. 2011). The application method involved spreading the feed evenly in the extraction machine (Biobase) and continually sprinkling it with a sprayer. It took approximately 20 minutes for the alcoholic spray to dry. Then the evenly sprayed dry feed was thoroughly turned over by hand.

\section{Parameters of treatments}

The experiment was carried out in the laboratory of fish biology at the University of Debrecen, Faculty of Agricultural and Food Sciences and Environmental Management. The fish fries under examination were from the local population of Szeged landrace common carp and they were provided by NAIK-HAKI from the artificial reproduction of 16 May 2017. The fish hatched on 19 May 2017. The experiment took place from the 45 to 80 days after hatching, which is in accordance with what is described in the literature (Nagy et al. 1981). Each treatment was repeated three times. The experiment was conducted in 15 pieces of
1801 capacity aquariums, all equipped with a unique biological filter and an air diffuser. 20 pieces of 45day-old mixed-sex common carp fries were placed in each of the aquariums. The aquariums also went through a daily $20 \%$ water change and substrate cleaning. Water temperatures and dissolved oxygen levels were also inspected on a daily basis (Hach HQ 30d) in three randomly selected aquariums. The average water temperature was $24.42 \pm 1.5{ }^{\circ} \mathrm{C}$ and the average dissolved oxygen level was $7.96 \pm 0.6 \mathrm{mg}$ per 1 during the experiment. These figures are considered optimal for common carp fry rearing. In the first 24 days the fish were given feed of $0.5 \mathrm{~mm}$ particle size Biomar Inico Plus (58\% crude protein, $15 \%$ crude fat), and for an additional 11 days on feed of $1.1 \mathrm{~mm}$ particle size (58\% crude protein, 18 crude fat) (Table $1)$. In the research we applied ad-libitum demandfeeding three times a day (Csorvási 2015).

Table 1

Feed composition

\begin{tabular}{lcc}
\hline \multicolumn{1}{c}{ Granule size } & $0.5 \mathrm{~mm}$ & $1.1 \mathrm{~mm}$ \\
\hline Crude protein & $58 \%$ & $58 \%$ \\
Crude fat & $15 \%$ & $18 \%$ \\
Ash & $11.20 \%$ & $10.80 \%$ \\
Crude fibre & $0.40 \%$ & $0.40 \%$ \\
Phosphorus & $1.70 \%$ & $1.71 \%$ \\
Calcium & $2.38 \%$ & $2.31 \%$ \\
Sodium & $1.04 \%$ & $0.94 \%$ \\
\hline
\end{tabular}

The examined four groups were placed in block layout so that the effects of external environmental factors (sunlight, air temperature) could be reduced (Table 2). The individual body weight of the fish was measured (with VWR SE $422-0.01 \mathrm{~g}$ precision) both at the beginning and at the end of the experiment during all the treatments and repetitions.

Aquariums arrangement

\section{Aquariums arrangement}

\begin{tabular}{|c|c|c|c|c|c|c|c|}
\hline Control & $50 \mathrm{ppm}$ & $75 \mathrm{ppm}$ & $100 \mathrm{ppm}$ & $500 \mathrm{ppm}$ & Control & $50 \mathrm{ppm}$ & 75 ppm \\
\hline $100 \mathrm{ppm}$ & $500 \mathrm{ppm}$ & Control & $50 \mathrm{ppm}$ & 75 ppm & $100 \mathrm{ppm}$ & $500 \mathrm{ppm}$ & \\
\hline
\end{tabular}

\section{Post-rearing}

The experimented groups of the separate treatments were relocated into 5 pieces of 350 litre recirculation aquaculture system (RAS). Depending on the survival rate we created 53-60 pieces per 3501 stock density groups. The post-rearing of the animals took place at this location up to their age of 5 months. During the post-rearing process, we measured the average weight by taking 20 sample pieces per treatment which also allowed to draw conclusions on the biomass. At the beginning of the research adlibitum demand-feeding was performed with $1.1 \mathrm{~mm}$, later on $3 \mathrm{~mm}$ and $4.5 \mathrm{~mm}$ feed particle sizes Biomar Efico Alpha in accordance with the growth of the fish (Table 3). Post-rearing is continued until the groups reach the $500 \mathrm{~g}$ average weight. For specimens of this size sex differentiation can be detected with great certainty (Nagy et al. 1981, Mubarik et al. 2011).

Table 3

Feed composition at post-rearing

\begin{tabular}{llc}
\hline \multicolumn{1}{c}{ Granule size } & $3 \mathrm{~mm}$ & $4.5 \mathrm{~mm}$ \\
\hline Crude protein & $40 \%$ & $43 \%$ \\
Crude fat & $23 \%$ & $14 \%$ \\
Ash & $3.4 \%$ & $5.7 \%$ \\
Crude fibre & $6.2 \%$ & $4.5 \%$ \\
Phosphorus & $0.85 \%$ & $0.86 \%$ \\
Calcium & $0.96 \%$ & $0.84 \%$ \\
Sodium & $0.29 \%$ & $0.15 \%$ \\
\hline
\end{tabular}




\section{DNA isolation and polymerase chain reaction (PCR)}

The sex identification of common carp specimens was carried out by DNA isolation. E.Z.N.A tissue kit (D3396-01) was used for the protease digestion of $30 \mathrm{mg}$ muscle tissue [h], fin [ú], mucus [n] in water for 90 minutes. The samples were stirred up with the aid of a vortex test tube shaker (Velp Scientifica, $z^{3}$ ) at the beginning of the isolation and shaken every 30 minutes for 10 seconds continuously. In the procedure RNase A digestion was used. A one-time centrifugation was conducted at $13000 \mathrm{~g}$ (Eppendorf $22{ }^{\circ} \mathrm{C}$ ) with $50 \mu \mathrm{l} 70{ }^{\circ} \mathrm{C}$ Elution Buffer. The DNA concentration of the samples was defined by a NanoDrop 1000 (Thermo Fisher Scientific) spectrophotometer. The resulting genomic DNA samples were stored at $-20{ }^{\circ} \mathrm{C}$ until further use.

Photometry results

\begin{tabular}{|c|c|c|c|c|c|}
\hline Pattern identification & Concentration (ng per ul) & A260* & A280** & $260 / 280 * * *$ & $260 / 230 * * * *$ \\
\hline h_ú1 & 964.29 & 19.286 & 10.191 & 1.89 & 2.36 \\
\hline h_ú2 & 1633.28 & 32.666 & 17.304 & 1.89 & 2.40 \\
\hline n_ú1 & 1374.27 & 27.485 & 14.397 & 1.91 & 2.42 \\
\hline n_ú2 & 1047.64 & 20.953 & 10.887 & 1.92 & 2.40 \\
\hline h_h1 & 803.37 & 16.067 & 8.365 & 1.92 & 2.38 \\
\hline h_h2 & 133.70 & 2.674 & 1.448 & 1.85 & 2.18 \\
\hline n_h1 & 259.93 & 5.199 & 2.830 & 1.84 & 2.29 \\
\hline n_h2 & 287.23 & 5.745 & 3.146 & 1.83 & 2.23 \\
\hline h_n1 & 480.32 & 9.606 & 5.208 & 1.84 & 2.29 \\
\hline h_n2 & 542.80 & 10.856 & 5.995 & 1.81 & 2.27 \\
\hline n_n1 & 269.52 & 5.390 & 2.851 & 1.89 & 2.59 \\
\hline $\mathrm{n} \_\mathrm{n} 2$ & 118.70 & 2.374 & 1.272 & 1.87 & 2.09 \\
\hline
\end{tabular}

Note: $* 260 \mathrm{~nm}$ absorbance (nucleic acids), ** $280 \mathrm{~nm}$ absorbance (proteins), $* * *$ with this ratio the purity of the isolated DNA solution can be measured for proteins (above 1.8 above pure), **** 260/230 (organic solvents, these can inhibit the PCR reaction) above 2.0 "clean" the isolate.

The three pairs of primers for sex-specific markers (Ccmf1, Ccmf2 and Ccmf3) were synthetized on the basis of sequences by Chen et al. (2009, 2010) described in their publication (Integrated DNA Technologies). The composition of the PCR mix relative to $10 \mu$ reaction medium: $1 \times$ GoTaq G2 buffer (Promega), $150 \mu \mathrm{m}$ dNTP mix (Fermentas), 2 $\mathrm{mm} \mathrm{MgCl}_{2}$ (Promega) $0.2 \mu \mathrm{m}$ forward primer, $0.2 \mu \mathrm{m}$ reverse primer, $0.05 \mathrm{U} / \mu \mathrm{l}$ GoTaq $\mathrm{G} 2$ polymerase, distilled water.

The parameters of the applied PCR program: (PTC-200 PCR instrument, Bio-Rad): initial denaturation $94{ }^{\circ} \mathrm{C}, 2$ minutes; denaturation $94{ }^{\circ} \mathrm{C}, 0.5$ minute; primer adhesion $60{ }^{\circ} \mathrm{C}, 0.5$ minute; synthesis $72{ }^{\circ} \mathrm{C}, 1$ minute; final synthesis $72{ }^{\circ} \mathrm{C}, 5$ minutes. The number of cycles was 30 . The resulting PCR product was verified by means of agarose gel electrophoresis. The agarose gel used in the procedure was $1.5 \mathrm{~m} / \mathrm{v} \%$ in $1 \times$ TAE buffer. The operation was run at $4 \mathrm{~V} / \mathrm{cm}$ voltage), which was stained with ethidium bromide (Biotium) DNA dye. The stained PCR products were made visible by UV light.

\section{Statistical analysis}

Statistical studies were performed using IBM SPSS Statistics 22. Within the groups, the homogeneity test was performed with a Levene test ( $\mathrm{P}$ $<0.05$ ) (Fehér et al. 2014). The effects of treatments and repetitions were determined by single-factor analysis of variance (ANOVA) for the initial and final body weight of the carp fries. Significant differences between the body weights of the stocks were determined by LSD (Nieoczym and Kloskowski 2014) and Tukey-test $(\mathrm{P}<0.05)$ (Csengeri et al. 2011).

The method used in the experiment to examine the survival rate of the fish was adopted by OMMI (OMMI 2001). For the calculation of feed conversation the most frequently used indicator was FCR (Rad et al. 2003, Przybyl and Mazurkiewicz 2004, Nasir 2016). In the formula FCR (g/g) = F/(WfWi) $(\mathrm{g} / \mathrm{g}), \mathrm{F}$ refers to the amount of dry feed consumed during the experiment $(\mathrm{g})$, Wf refers to the final body weight $(\mathrm{g})$, and $\mathrm{Wi}$ stands for the initial body weight $(\mathrm{g})$. To examine the growth rate of the fish, the SGR indicator was used (Busacker et al. 1990, Hopkins 1992, Lee et al. 1999). In the formula SGR $(\%)=(\operatorname{lnWf}-\ln W i) / \mathrm{t} \times 100$, Wf refers to the final body weight $(\mathrm{g})$, Wi stands for the initial body weight $(\mathrm{g})$, and $\mathrm{t}$ indicates the number of days.

\section{RESULTS}

The parameters we measured for water quality did not indicate any harmful values for the fish. The overall results of the groups are shown in Table 6 . 
Results (mean + standard deviation) $(\mathrm{P}<\mathbf{0 . 0 5})$

\begin{tabular}{lccccc}
\hline & $\mathrm{T}_{\text {Control }}$ & $\mathrm{T}_{50}$ & $\mathrm{~T}_{75}$ & $\mathrm{~T}_{100}$ & $\mathrm{~T}_{500}$ \\
\hline Initial average weight $(\mathrm{g})$ & $0.16 \pm 0.06^{\mathrm{a}}$ & $0.16 \pm 0.04^{\mathrm{a}}$ & $0.17 \pm 0.08^{\mathrm{a}}$ & $0.17 \pm 0.13^{\mathrm{a}}$ & $0.16 \pm 0.11^{\mathrm{a}}$ \\
Final average weight $(\mathrm{g})$ & $4.59 \pm 1.81^{\mathrm{a}}$ & $4.70 \pm 1.70^{\mathrm{a}}$ & $4.30 \pm 1.67^{\mathrm{a}}$ & $4.63 \pm 2.56^{\mathrm{a}}$ & $4.24 \pm 2.61^{\mathrm{a}}$ \\
Survival \% & $100 \pm 0$ & $100 \pm 0$ & $95 \pm 8.66$ & $100 \pm 0$ & $96.67 \pm 5.77$ \\
FCR & 0.71 & 0.75 & 0.82 & 0.73 & 0.85 \\
SGR \% & $9.52 \pm 0.14$ & $9.45 \pm 0.22$ & $9.03 \pm 0.20$ & $9.35 \pm 0.17$ & $9.18 \pm 0.48$ \\
\hline
\end{tabular}

The average weight per treatments is illustrated in Figure 1. The survival rate does not correlate with the average weight in our case, which is due to low population density. The highest survival rates were obtained in treatments $\mathrm{T}_{\text {Control }}, \mathrm{T}_{50}, \mathrm{~T}_{100}$ with a $100 \%$ ratio. The mortality rate was not significant in any of the treatments. The lowest survival rate was measured in treatment $\mathrm{T}_{75}$ with a $95 \%$ ratio. The survival rates are illustrated in Figure 2.

Figure 1: Initial and final average weights

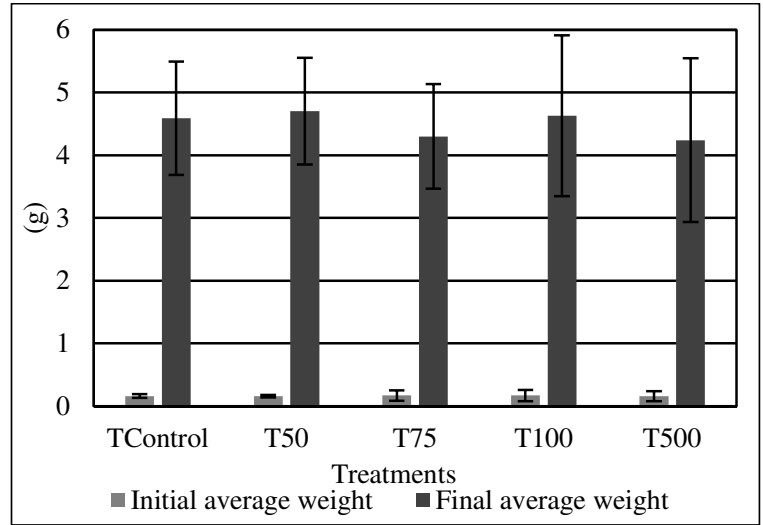

Figure 2: Survival \%

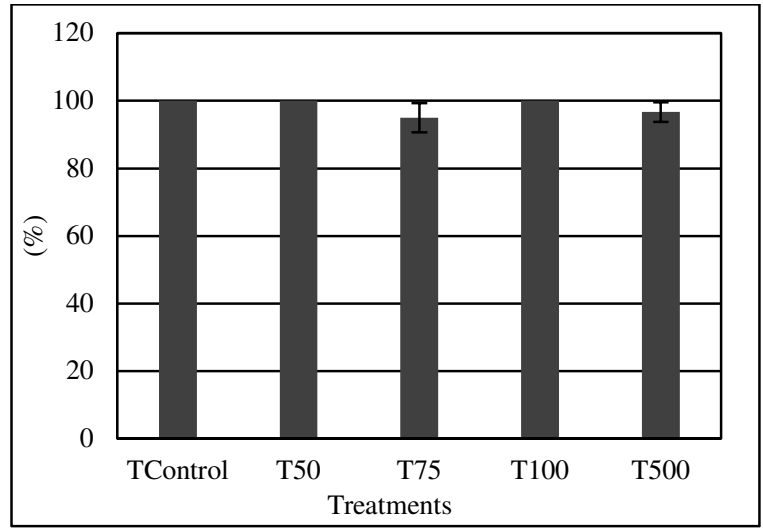

In Figure 3 we indicated the amount of the original biomass at the start of the research by showing the total weight of the common carp per treatment. At the beginning of the treatment we tried to create homogeneous stocks by sorting out male and female specimens, it can be clearly seen in Table 1 and Figure 1. The individual body weights of the assorted groups were tested by the IBM SPSS Statistics 22 program which proved that the groups were homogenous. The results of growth efficiency after the applied hormone treatments compared to those of the control group and to each other had no significant differences.

Figure 3: Biomass changes under 35 days

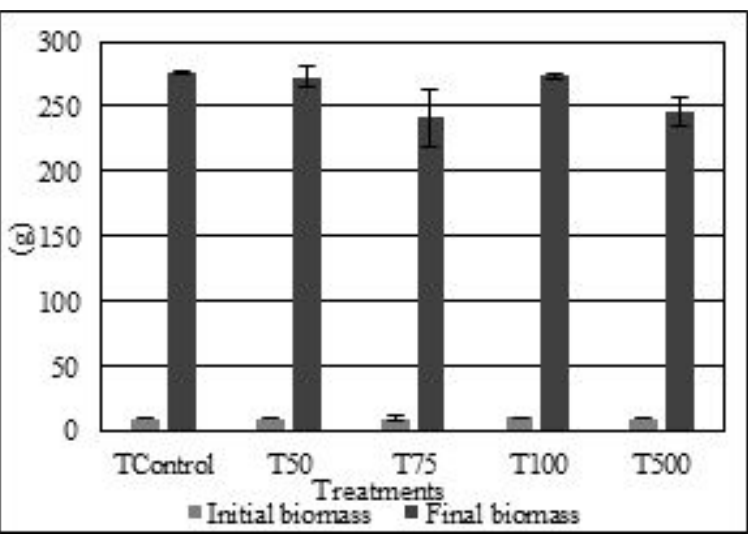

By examining the treatments separately, it becomes obvious that the fish were growing nearly at the same rate in each group, which is supported by the values of the specific growth rate (SGR). By examining the treatments collectively, there is no significant difference in the FCR values. Table 7 reveals the amount of feed consumed by the groups.

The values for specific growth rate (SGR) and feed conversion ratio (FCR) are shown in Table 8.

Consumed feed (g)

\begin{tabular}{|c|c|c|c|c|c|}
\hline Granule size & $\mathrm{T}_{\text {Control }}$ & $\mathrm{T}_{50}$ & $\mathrm{~T}_{75}$ & $\mathrm{~T}_{100}$ & $\mathrm{~T}_{500}$ \\
\hline $0.5 \mathrm{~mm}$ & 93.3 & 94.21 & 89.43 & 95.28 & 96.34 \\
\hline $1.1 \mathrm{~mm}$ & 95.5 & 102.00 & 99.00 & 97.00 & 105.00 \\
\hline Total & 188.8 & 196.21 & 188.43 & 192.28 & 201.34 \\
\hline
\end{tabular}


Feed Conversation Ratio and Special Growth Rate values

\begin{tabular}{lcc}
\hline & SGR $(\%)$ & FCR $(\mathrm{g} / \mathrm{g})$ \\
\hline $\mathrm{T}_{\text {Control }}$ & 9.52 & 0.71 \\
$\mathrm{~T}_{50}$ & 9.55 & 0.75 \\
$\mathrm{~T}_{75}$ & 9.17 & 0.82 \\
$\mathrm{~T}_{100}$ & 9.35 & 0.73 \\
$\mathrm{~T}_{500}$ & 9.28 & 0.85 \\
\hline
\end{tabular}

Table 9 demonstrates that in the post-rearing phrase we experienced continuous biomass growth as well as low mortality rate with each group compared to the initial values of the experiment.
As part of the supplementary work sex-specific identification was tested by PCR as described by a Chen et al. (2009, 2010), however, the use of this method proved unreliable. DNA isolation from all the three sample types (muscle tissue, fin and mucus) was successful. The ccmf1 and ccmf3 markers did not function based on the described method because not only the PCR product size was visible on agarose gel (Table 4). For the ccmf 2 marker, a single product was obtained, which in turn was not sex-specific. The ccmf 2 marker was repeated, but the male marker continued to appear on the phenotype, even on female subjects.

Biomass (kg) and survival \% changes at post-breeding

\begin{tabular}{lcccccc}
\hline \multicolumn{1}{c}{ Date } & $\mathrm{T}_{\text {Control }}$ & $\mathrm{T}_{50}$ & $\mathrm{~T}_{75}$ & $\mathrm{~T}_{100}$ & $\mathrm{~T}_{500}$ & $\mathrm{Total}$ \\
\hline 06 September & 1.68 & 1.67 & 1.85 & 2.02 & 1.62 & 8.84 \\
20 September & 3.21 & 3.07 & 3.07 & 3.38 & 3.09 & 15.81 \\
04 October & 4.59 & 4.23 & 3.51 & 3.52 & 3.95 & 19.80 \\
18 October & 5.91 & 4.79 & 5.31 & 5.75 & 5.44 & 27.21 \\
\hline Survival \% & 96.6 & 96.6 & 80.0 & 95.0 & 91.6 \\
\hline
\end{tabular}

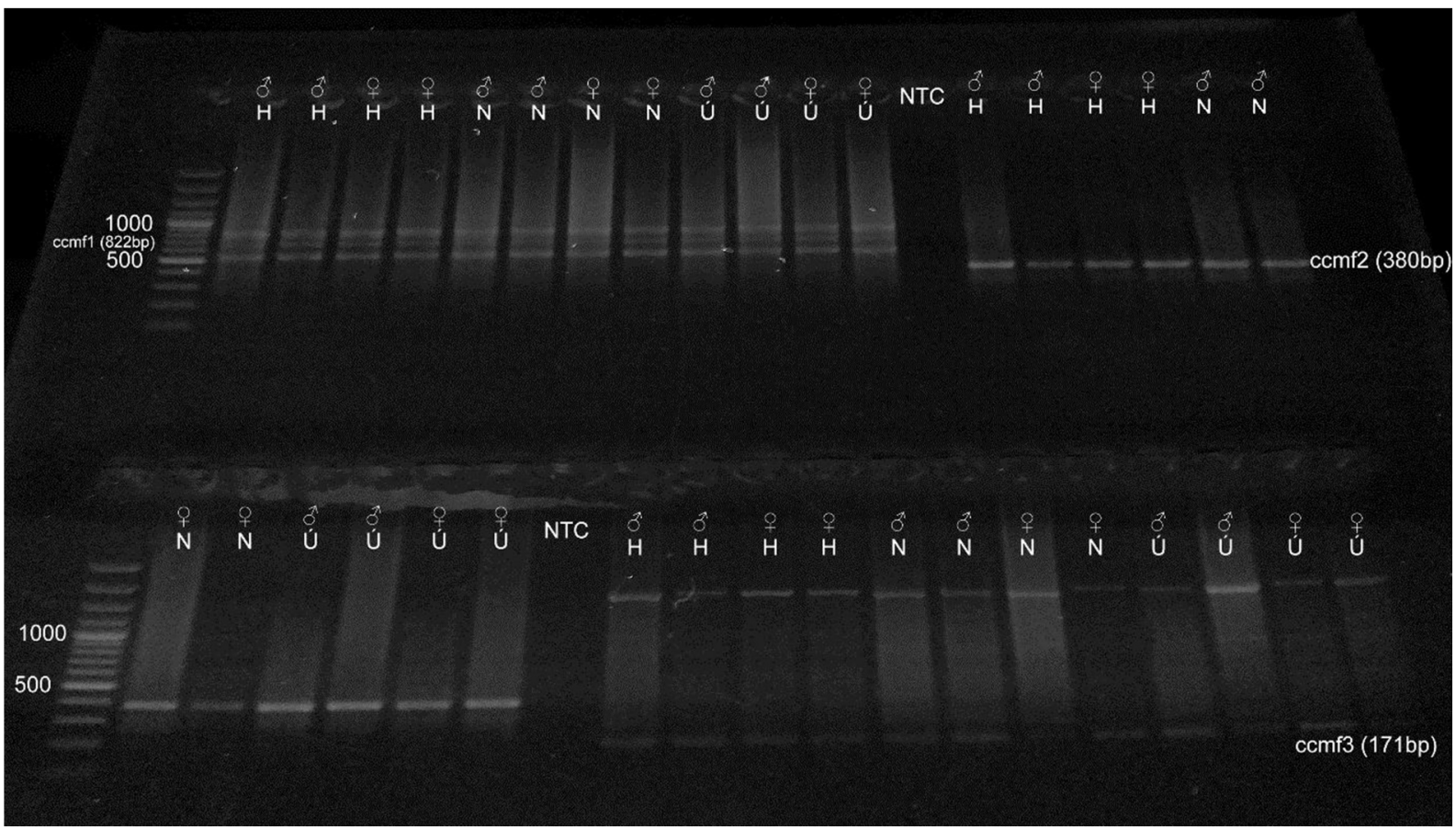

Explanation: In the picture the examination of the three sample types, muscle tissue [h], fin [ú], mucus [n] can be seen together with the ccmf1, ccmf2 and ccmf3 markers. Ccmf2 is usable, however, there is no visible difference between the male $[\hat{O}]$ and female [] samples. NTC (No Template Control), Generuler 50 bp DNA marker was used (Thermo Fisher Scientific).

\section{CONCLUSIONS}

The results of the experiment showed that statistically significant differences in body weight gain were not detectable. The uniformity of homogeneous stocks at the start of the experiment remained unchanged by the end of the research too. For each group, 95\% survival rate or even higher was observed at the end of the hormone-treated period. On the basis of the biomass harvested at the end of the experiment, 
the FCR and SGR figures show that the hormone treatment did not affect the production parameters of the fish at this stage of fry rearing. Even the postrearing stage is characterized by low mortality rate and continuous weight gain, which means that common carp can be introduced to our recirculation aquaculture system.

The aim of the experiment is to find out how successful hormonal sex reversal can be with the method we applied. The sex of the fish can be identified by autopsy and by microscopic gonad test after the groups reach the $500 \mathrm{~g}$ average weight. On the basis of the resulting sex ratios, we can make conclusion about the efficiency of sex-reversal.

During the PCR experiment, it was found that with the tested ccmf2 male-specific marker, male specimens could not be identified with reliable results. The failure of the test is due to the fact that a successful experiment conducted by the authors can only be used for a local variant of common carp, for the Yellow River population. The sex-specific identification of the common carp with other PCR markers and other non-invasive sampling technology requires further research in the future.

\section{ACKNOWLEDGEMENT}

The work was supported by the European Regional and Development Fund and the Government of Hungary within the project GINOP-2.3.2-15-201600025. We especially thank Levente Czeglédi (Associate Professor) for his professional support.

The work/publication is supported by the EFOP3.6.3-VEKOP-16-2017-00008 project. The project is co-financed by the European Union and the European Social Fund.

\section{REFERENCES}

Ben-Dom, N.-Cherfas, N. B.-Gomelsky, B.-Avtalion, R. R.-Moav, B.-Hulata, G. (2001): Production of heterozygous and homozygous clones of common carp (Cyprinus carpio): Evidence from DNA fingerprinting and mixed leukotyce reaction. The Israeli Journal of Aquaculture Bamidgeh. 53. 3-4: 89-100.

Busacker, G. P.-Adelman, I. R.-Goolish, E. M. (1990): Growth [In: Shreck, C. B.-Moyle, P. B. (eds.) Methods for fish biology.] American Fisheries Society. Bethesda. 363-388.

Cherfas, N. B.-Hulata, G.-Kozinsky, O. (1993): Induced diploid gynogenesis and polyploidy in ornamental (koi) carp (Cyprinus carpio L.) 2. Timing of heat shock during the first cleavage. Aquaculture. 111: 281-290.

Cherfas, N. B.-Gomelsky, B.-Ben-Dom, N.-Joseph, D.-Cohen, S (1996): Assessment of all-female common carp progenies for fish culture. The Israeli Journal of Aquaculture Bamidgeh. 48: 149-157.

Chen J.-Wang Y.-Yue Y.-Xia X.-Du Q.-Chang Z. (2009): A novel male-specific DNA sequence in the common carp, Cyprinus carpio. Molecular and Cellular Probes. 5. 23: 235239

Chen, J.-Du, Q.-Yue, Y.-Dang, B.-Chang, Z. (2010): Screening and identification of male $\square$ specific DNA fragments in common carps Cyprinus carpio using suppression subtractive hybridization. Journal of Fish Biology. 2. 77: 403-413.

Colborn, T.-Saal, F. S. V.-Soto, A. M. (1993): Developmental effects of endocrine-disrupting chemicals in wildlife and humans. Environmental Health Perspectives. 101: 378-384.

Csengeri I.-Gál D.-Kosáros T.-Pekár F.-Bakos J.-Potra F.-Kovács Gy.-Feledi T.-Fazekas J.-Biró J.-J. Sándor Zs.-Gy. Papp Zs.Jeney Zs.-Rónyai A. (2011): A Haltakarmányozás halliszt és halolaj nélkül? Állattenyésztés és Takarmányozás. 60. 3: 281294

Csorvási É.-Saboura Z.-Fehér M.-Juhász P.-Stündl L.-Bársony P. (2015): Bioaktív takarmány-kiegészítők hatása intenzíven nevelt pontyivadék (Cyprinus carpio) termelési paramétereire. Agrártudományi Közlemények. 65: 35-41.

Damstra, T.-Barlow, S.-Bergman, A.-Kavlock, R.-Kraak, G. V. D. (2002): WHO Report on Global Assessment of the State of the Science of Endocrine Disruptors. http://www.who.int/ipcs/ publications/en/frontcover.pdf
Devlin, R. H.-Nagahama, Y. (2002): Sex determination and sex differentiation in fish: an overview of genetic, physiological, and environmental influences. Aquaculture. 208: 191-364.

Hamid, F. L.-Hadi, E. C.-Mahboobeh, R. R.-Hamed, M. S. (2014): Sex reversal, mortality rate and growth performance of platy Xiphophorus variatus (Poeciliidae) treated by methyltestosterone Poeciliid Research. 4. 1: 6-12. http://www. pr.bioflux.com.ro/

Fehér M.-Baranyai E.-Simon E.-Juhász P.-Csorvási É.-Bársony P.-Stündl L. (2014): Esszenciális nyomelemek alkalmazása a barramundi (Lates calcarifer) ivadéknevelésében. Agrártudományi Közlemények. 57: 33-38.

Gomelsky, B. (2003): Chromosome set manipulation and sex control in common carp: A review. Aquatic Living Resources. 16: 408-415

Horváth, L.-Orbán, L. (1995): Genome and gene manipulation in the common carp. Aquaculture. 129: 157-181.

Hopkins, K. D. (1992): Reporting fish growth: a review of the basics. Journal of the World Aquaculture Society. 23: 173-179.

Hulak, M.-Kocour, M.-Gela, D.-Rodina, M.-Linhart, O. (2007): Polluted water by $17 \alpha-$ MT provides successful male sex reversal of common carp (Cyprinus carpio L.) from gynogenetic offspring. University of South Bohemia, Research Institute of Fish Culture and Hydrobiology. 389: 25.

Jensi, A.-Karal, M. M.-Rajkumar, R.-Jeya, S. P. (2016): Chidambaram Effect of $17 \alpha$-methyl testosterone on sex reversal and growth of Nile tilapia (Oreochromis niloticus L., 1758) Ecology, Environment and Conservation 22. 3: 14931498.

Molnár, K. (2009): Data on the parasite fauna of the European common carp (Cyprinus carpio carpio) and Asian common carp (Cyprinus carpio haematopterus) support an Asian ancestry of the species. AACL Bioflux. 2. 4: 391-400.

Kocour, M.-Linhart, O.-Gela, D. (2003): Results of comparative growing test of all-female and bisexual population in two-yearold common carp (Cyprinus carpio L.) Aquaculture International. 11: 369-378. 
Kocour, M.-Linhart, O.-Gela, D.-Rodina, M. (2005): Growth Performance of All-Female and Mixed-Sex Common Carp (Cyprinus Carpio L.) Populations in the Central Europe Climatic Conditions Journal of the World Aquaculture Society. 36. 1: 103-113.

Komen, J.-Duynhouwer, J.-Richter, C. J. J.-Huisman, E. A. (1988): Gynogenesis in Common Carp (Cyprinus carpio L.) I. Effects of Genetic Manipulation of Sexual Products and Incubation Conditions of Eggs. Aquaculture. 69: 227-239.

Komen, J.-Bongers, A.-Richter, C. J. J.-Muiswinkel, W. B.Huisman, E. (1991): Gynogenesis in common carp (Cyprinus carpio L.) II. The production of homozygous gynogenetic clones and F1 hybrids. Aquaculture. 92: 127-142.

Komen, J.-Wiegertjes, G. F.-Ginneken, V. J. T.-Eding, E. H.Richter, C. J. J. (1992): Gynogenesis in Common Carp (Cyprinus carpio L.) III. The effect of inbreeding on gonadal development of heterozygous and homozygous gynogenetic offspring. Aquaculture. 104: 51-66.

Komen, J.-Eding, E. H.-Bongers, A.-Richter, C. J. J. (1993) Gynogenesis in common carp (Cyprinus carpio L.) IV. Growth, phenotypic variation and gonad differentiation in normal and methyltestosterone treated homozygous clones and F1 hybrids. Aquaculture. 111: 271-280.

Komen, J.-Spaans, P.-Zhang, D. M.-Richter, C. J. J. (1995): Sex determination in Common Carp (Cyprinus carpio L.). Aquaculture. 137: 103-108.

Komen, H.-Thorgaard, G. (2007): Androgenesis, gynogenesis and the production of clones in fishes: a review. Aquaculture. 269: $150-173$.

Lee, T. M.-Chang, Y. C.-Lin, Y. H. (1999): Differences in physiological responses between winter and summer Gracilaria tenuistipitata (gigartinales, rhodophyta) to varying temperature. Botanical Bulletin of Academia Sinica. 49: 93-100.

Nagy, A.-Bercsényi, M.-Csányi, V. (1981): Sex reversal in carp (Cyprinus carpio L.) by oral administration of methyltestosterone. Canadian Journal of Fisheries and Aquatic Science. 38: 725-728.
Nasir, N. (2016): Growth development of young common carp (Cyprinus carpio L.) through dietary sodium chloride supplementation. Mesopotamia Environment Journal. 2. 2: 1218.

Nieoczym, M.-Kloskowski, J. (2014): The role of body size in the impact of common carp (Cyprinus carpio L.) on water quality, zooplankton, and macrobenthos in ponds. International Review of Hydrobiology. 99: 212-221.

Mubarik, M. S.-Ahmed, I.-Mateen, A.-Iqbal, T. (2011): 17 $\alpha-$ Methyltestosterone induced masculinization and its effect on growth and meat quality of Cyprinus carpio L. International Journal of Agriculture and Biology. 13: 971-975.

Piferrer, F. (2001): Endocrine sex control strategies for the feminization of teleost fish. Aquaculture. 197: 229-281.

Przybyl, A.-Mazurkiewicz, J. (2004): Nutritive value of cereals in feeds for common carp (Cyprinus carpio L.). Czech Journal of Animal Science. 49. 7: 307-314.

Rad, F.-Köksal, G.-Kindir, M. (2003): Growth performance and food conversion ratio of Siberian sturgeon (Acipenser baeri Brandt) of different daily feeding rates. Turkish Journal of Veterinary and Animal Science. 27: 1085-1090.

Singh, A. K. (2013): Introduction of modern endocrine techniques for the production of monosex population of fishes. General and Comparative Endocrinology. 181: 146-155.

Shelton, W. L.-Wanniasingham, V.-Hiott, A. E. (1995): Ovarian differentiation in common carp (Cyprinus carpio L.) in relation to growth rate. Aquaculture. 137: 203-211.

Sumpter, J. P. (2005): Endocrine disrupters in the aquatic environment: an overview. Acta Hydrochemistry Hydrobiology. 33: 9-16.

OMMI - Országos Mezőgazdasági Minősítő Intézet (2001): Ponty teljesítményvizsgálati kódex 3. Országos Mezőgazdasági Minősítő Intézet. Budapest. 